\title{
ON AN OSTROWSKI TYPE INEQUALITY FOR A RANDOM VARIABLE
}

\author{
I. BRNETIĆ AND J. PEČARIĆ
}

Abstract. An Ostrowski's type inequality for a random variable is improved and one application is given.

Mathematics subject classification (1991): 26D15.

Key words and phrases: Ostrowski's type inequality, Beta random variable.

\section{REFERENCES}

[1] S. S. DRAGomiR, N. S. BARNETT AND S. WANG, An Ostrowski type Inequality for a Random Variable Whose Probability Density Function Belongs to $L_{p}[a, b], p>1$, Math.Inequal.Appl. 2 (1999), 501-508.

[2] A. M. FINK, Bounds on the Deviation of a Function from its Averages, Czechoslovak Math.J. 42 (1992), 289-310.

[3] D. S. Mitrinović, J. E. PeČARIĆ AND A. M. FinK, Inequalities Involving Functions and Their Integrals and Derivatives, Kluwer Academic Publishers, Dordrecht, Boston, London, 1991. 